Short Communication

Animal Genetics

\title{
Cytochrome b sequence of the Mazama americana jucunda Thomas, 1913 holotype reveals Mazama bororo Duarte, 1996 as its junior synonym
}

\author{
Aline Meira Bonfim Mantellatto ${ }^{1}$ (D), Susana González ${ }^{2}$ (D) and José Maurício Barbanti Duarte ${ }^{1}$ \\ ${ }^{1}$ Universidade Estadual Paulista (UNESP), Faculdade de Ciências Agrárias e Veterinárias, Núcleo de \\ Pesquisa e Conservação de Cervídeos, Jaboticabal, SP, Brazil. \\ ${ }^{2}$ Instituto de Investigaciones Biológicas Clemente Estable, Departamento de Biodiversidad y Genética, \\ Montevideo, Uruguay.
}

\begin{abstract}
The small red brocket deer, Mazama bororo Duarte, 1996 was described based on karyotypical and morphological characters. However, the original description of Mazama americana jucunda suggested that this subspecies could represent the same taxon as Mazama bororo. This assumption was based on the type locality of Mazama americana jucunda and on morphological similarities between Mazama americana jucunda and Mazama bororo. To solve this question, we obtained DNA sequences of the holotype of Mazama americana jucunda and compared it with other species of Mazama, including the holotype of $M$. bororo. A phylogenetic tree was obtained to verify the relationships among these taxa. The results clearly showed that $M$. americana jucunda and $M$. bororo represent the same biological entity. Therefore, the oldest name available for the small red brocket occurring in the Atlantic Forest of southern Brazil should be Mazama jucunda, remaining $M$. bororo as a junior synonym. We emphasise the importance of using DNA from museum specimens, especially from holotypes, in order to obtain a more accurate taxonomic identification. We also highlight the importance of application of valid names for labelling all aspects of biodiversity research, as well as for monitoring and conservation efforts.
\end{abstract}

Keywords: Cytochrome b, small red brocket deer, taxonomy, phylogenetic analysis, Atlantic Forest.

Received: April 04, 2021; Accepted: September 21, 2021.

Natural history collections are unique repositories of biodiversity, offering great opportunities for genetic research that can be applied in taxonomy and conservation (Burrel et al., 2015). The number of taxonomic studies using DNA obtained from specimens deposited in natural history collections has increased mainly due to the use of the mitochondrial genes (Hajibabaei et al., 2007). Such availability of sequences obtained from type specimens can provide additional data for poorly known taxa, which facilitates the description of new species and taxonomic revisions (Chakrabarty, 2010; Strutzenberger et al., 2012).

The existence of several cryptic species of Mazama is considered one of the more impressive striking case of morphological convergence within mammals (Gilbert et al., 2006), remaining doubts to analyse the evolutionary relationships (Duarte et al., 2008). The monophyly of this genus was refuted by molecular analyses using mitochondrial and nuclear loci (Gilbert et al., 2006; Duarte et al., 2008; Gutiérrez et al., 2017).

The small red brocket deer, Mazama bororo, was proposed by Duarte in 1996 based on morphological (Duarte, 1996) and cytogenetic characterisation (Duarte and Giannoni, 1996; Duarte and Jorge, 2003). This classification was predominantly based on karyotype differences, as $M$. bororo

Send correspondence to José Maurício Barbanti Duarte. Universidade Estadual Paulista (UNESP), Faculdade de Ciências Agrárias e Veterinárias, Núcleo de Pesquisa e Conservação de Cervídeos, Via de Acesso Professor Paulo Donato Castellane, s/nº, 14884-900, Jaboticabal, SP, Brazil. E-mail: mauricio.barbanti@unesp.br. had a completely different chromosomal pattern, suggesting its probable reproductive isolation from other Mazama (Vogliotti and Duarte, 2012). External body measurements of $M$. bororo were intermediate between M. americana and M. nana, and very close to those of hybrids between the latter two species (Duarte and Jorge, 2003). The hybrids between M. americana and $M$. nana, although morphologically similar to M. bororo, have the chromosomal set of both parents and, therefore, are easily distinguishable by cytogenetic analyses (Vogliotti and Duarte, 2012).

Morphological studies of Mazama specimens based on skeletons and skins from different Brazilian collections did not detect significant differences among $M$. bororo from $M$. americana (Vogliotti and Duarte, 2010). However, specific traits are potentially discriminant for the species, including weight, height, body length, thorax circumference, and the lengths of the metacarpus and metatarsus (Duarte and Jorge, 2003), at least in living animals or recently decreased specimens (Vogliotti and Duarte, 2010).

The name Mazama americana jucunda Thomas, 1913 is the oldest taxon of Mazama with the type locality in Brazil. The type specimen was collected in 1901, in the region of Roça Nova, on the Serra do Mar, state of Paraná, Brazil, in a region where currently inhabits $M$. bororo. In addition, the morphological description closely resembles the characteristics of M. bororo, as described by Duarte (1996). Thomas described $M$. a. jucunda as smaller than the other known species of Mazama, with the upper part of the limbs showing a reddish-brown colour on the metacarpals, and a darker tail in the dorsal region. Considering that the taxon 
described as $M$. bororo may be conspecific to $M$. a. jucunda, we used mitochondrial DNA sequences from the holotypes to investigate the possible synonymy between these two taxa.

A total of 38 specimens of Mazama and one of Ozotoceros bezoarticus were analysed for genetic comparisons. We used 28 DNA sequences available on Genbank and 11 DNA sequences produced by this work also deposited in GenBank (Table 1). We extracted DNA samples from hairs of nine specimens of $M$. bororo, one of the $M$. a. jucunda holotype and one specimen of $O$. bezoarticus which was stored at Núcleo de Pesquisa e Conservação de Cervídeos (NUPECCE) tissue and cell bank. All samples were collected at a maximum of 30 years ago, except for the M. a. jucunda, which was collected 119 years ago. To extract DNA from $M$. a. jucunda we used a small fragment from a skull provided by the Natural History Museum (BMNH), London (specimen BMNH 3.7.1.103).

We extracted DNA from hair samples using the protocol described by Sambrook et al. (1989), where a 224 base pair (bp) fragment of the cytochrome b mitochondrial gene was amplified using the primer pair IDMAZ224L (5' CATCCGACACAATAACAGCA 3') and IDMAZH, (5'TCCTACGAATGCTGTGGCTA3') described by González et al. (2009).

Cytochrome $b$ fragments from hair DNA samples were amplified in a conventional thermocycler (Biometra T One Thermocycler), and the amplification reaction was performed in a final volume of $25.0 \mu \mathrm{L}$, containing: 1 x ImmoMix ${ }^{\mathrm{TM}}$ (Bioline), $0.3 \mu \mathrm{M}$ of each primer, $0.3 \mu \mathrm{M}$ of bovine serum albumin, $15 \mathrm{ng} / \mu \mathrm{L}$ of DNA and $7.6 \mu \mathrm{L}$ of water. The polymerase chain reaction (PCR) amplification conditions were $95^{\circ} \mathrm{C}$ for $5 \mathrm{~min}, 35$ cycles at $95^{\circ} \mathrm{C}$ for $1 \mathrm{~min}, 55^{\circ} \mathrm{C}$ for $1 \mathrm{~min}, 72^{\circ} \mathrm{C}$ for $1 \mathrm{~min}$; and a final extension at $72^{\circ} \mathrm{C}$ for $10 \mathrm{~min}$. PCR products were visualised on $1 \%$ agarose gel to verify the success in amplification and checked for the size of the fragments based on the $1 \mathrm{~kb}$ plus DNA ladder marker (Invitrogen).

DNA extraction from the M. a. jucunda holotype was performed following the protocol described by González et al. (2015), and also a 224 base pair (bp) fragment was amplified using the same primer pair described above. To minimise the risks of contamination and ensure the reliability of the results, negative controls were used in all DNA extractions and during the PCR, which was performed three different times, in two different laboratories. PCR amplification for the DNA sample from the BMNH collection was performed in a final volume of $20.0 \mu \mathrm{L}$, containing: 1 x SensiFAST ${ }^{\text {TM }}$ HRM kit, $0.8 \mu \mathrm{M}$ of primer, $0.3 \mu \mathrm{L}$ BSA, $10 \mathrm{ng} / \mu \mathrm{L}$ of DNA and $6.9 \mu \mathrm{L}$ of water. The real-time thermocycler (Rotor-Gene, Corbet ${ }^{\mathrm{TM}}$ ) programming was: $95^{\circ} \mathrm{C}$ for $2 \mathrm{~min}, 95^{\circ} \mathrm{C}$ for $5 \mathrm{~s}, 54^{\circ} \mathrm{C}$ for $10 \mathrm{~s}$ ( 10 cycles $)$, then $54^{\circ} \mathrm{C}$ for $10 \mathrm{~s}$ ( 15 cycles $), 53^{\circ} \mathrm{C}$ for 10 $\mathrm{s}$, and $72^{\circ} \mathrm{C}$ for $20 \mathrm{~s}$. After purifying the samples, according to the protocol described by Dorado-Pérez (2012), each of the amplified samples were sequenced individually with the same primers (forward and reverse) used in amplification in an Applied Biosystems 3730xL automated sequencer.

The quality of the sequences obtained was analysed visually and using the PHRED software, contained in Codon Code Aligner v. 6.0.2. Sequences with less than 50 base-pairs with PHRED 20 were excluded. Sequence alignment was performed by the PHRED Clustal W (Thompson et al., 1994), contained in BioEdit v. 7.2.5 (Hall, 1999). All the sequences used in this work were aligned and restricted to $224 \mathrm{bp}$ cytb fragment. To infer the best nucleotide substation model for the dataset, the sequences were analysed in jModelTest v. 2.1.6 (Darriba et al., 2012) as implemented in the CIPRES Science Gateway (Miller et al., 2010). The criterion used to select the best model was the Bayes information criterion (BIC), and the Hasegawa Kishino and Yano (HKY) model + Gamma was selected. Sequences for the mitochondrial $C y t-b$ gene were obtained by $224 \mathrm{bp}$ fragment. The software BEAST v. 1.8.1 (Drummond et al., 2012) was used to infer the tree based on Bayesian Inference, and the Markov chains were run for 25,000,000 generations; trees were sampled every 1000 generations. A $25 \%$ burn-in was adopted. Therefore, the first 6,250,000 generations (6250 trees) were discarded as burn-in, and posterior probability estimates of all model parameters were based on the remaining $(18,751)$ trees. The convergence between races was verified using the software Tracer v.1.6 and only effective sample size (ESS) results higher than 200 were accepted. The resulting trees were condensed in the programme Tree Annotator and were visualised using the programme Fig Tree, v.1.3.1 (Rambaut, 2010). Sequences of samples belonging to the M. americana, M. bororo, $M$. $a$. jucunda, M. gouazoubira, M. nana, M. nemorivaga and $O$. bezoarticus were used for phylogenetic tree inference (Table 1). The sequence of $O$. bezoarticus, M. gouazoubira and $M$. nemorivaga were used to root the tree, because these species belonged to the subtribe Blastocerina, and the group of the red brocket deer (M. americana, M. bororo, and M. nana) belonged to the subtribe Odocoileina (Gutiérrez et al., 2017; Heckeberg, 2020).

As a result, we identified 25 different haplotypes of the 39 sampled individuals. Among the 13 sequences of $M$. bororo analysed, we found four different haplotypes, and among the 19 sequences of $M$. americana analysed, we found 14 different haplotypes. For the others species (M. nana, $M$. gouazoubira, M. nemorivaga and O. bezoarticus) and subspecies (M.a.jucunda) were detected as unique haplotypes for each analysed sequence (Table 1).

The Bayesian Inference analysis (Figure 1) showed that the sequence of the M. a. jucunda holotype was nested within the clade of $M$. bororo sequences and this clade showed high posterior probability support (=1.0). A clear divergence was verified between $M$. a. jucunda and $M$. americana particularly considering the existence of $M$. bororo. The clades of $M$. americana and $M$. bororo are clearly separated by a posterior probability support (posterior probability of 0.95 ). Indeed, the fact of M. a. jucunda was not grouped on the M. americana clade highlighting that it may not be a subspecies of $M$. americana. Our result suggests that $M$. a. jucunda and $M$. bororo represent the same biological entity.

The possibility of obtaining DNA sequences from a type specimen of more than a hundred years old was essential to clarify the taxonomic identity of $M$. a. jucunda. Besides showing that M. a. jucunda is not a geographical race, or a subspecies, of $M$. americana, we demonstrate that this taxon is molecularly compatible with the species $M$. bororo, corroborating the similar morphometric and geographic data 
Table 1 - Mitochondrial cytochrome $b$ sequences used for phylogenetic inference among several Mazama specimens.

\begin{tabular}{|c|c|c|c|}
\hline Species & Sample identification & GenBank Access & Origin/Source \\
\hline \multirow{19}{*}{ Mazama americana } & $\mathrm{T} 16$ & DQ789209.2 & Cuiabá-MT. Brazil/Captivity \\
\hline & $\mathrm{T} 18$ & DQ789211.2 & Vilhena-RO. Brazil/Captivity \\
\hline & $\mathrm{T} 21$ & DQ789216.2 & Ariquemes-RO. Brazil/Captivity \\
\hline & $\mathrm{T} 22$ & DQ789217.2 & Ariquemes-RO. Brazil/Captivity \\
\hline & $\mathrm{T} 28$ & DQ789218.2 & Rio Branco-AC. Brazil/Captivity \\
\hline & $\mathrm{T} 35^{1}$ & DQ789221.2 & Belém Zoo-AM. Brazil/Captivity \\
\hline & $\mathrm{T} 36^{1}$ & DQ789222.2 & Projeto Jari-PA. Brazil/Captivity \\
\hline & T39 & DQ789223.2 & Parauapebas-PR.Brazil/Captivity \\
\hline & $\mathrm{T} 40^{2}$ & DQ789224.2 & Carajás-PA. Brazil/Captivity \\
\hline & $\mathrm{T} 41$ & DQ789225.2 & Carajás-PA. Brazil/Captivity \\
\hline & $\mathrm{T} 43$ & MG786262 & Carajás-PA. Brazil/Captivity \\
\hline & $\mathrm{T} 70^{3}$ & DQ789230.2 & Ciudad del Este.Paraguay/Captivity \\
\hline & $\mathrm{T} 110^{3}$ & DQ789201.2 & Terra Boa-PR. Brazil/Captivity \\
\hline & $\mathrm{T} 120^{3}$ & DQ789204.2 & Unknown/Captivity \\
\hline & $\mathrm{T} 161^{4}$ & DQ789207.2 & Carajás-PA. Brazil/Captivity \\
\hline & $\mathrm{T} 164^{4}$ & DQ789208.2 & Carajás-PA. Brazil/Captivity \\
\hline & $\mathrm{T} 192^{2}$ & DQ789212.2 & Unknown/Captivity \\
\hline & $\mathrm{T} 205$ & DQ789215.2 & Foz do Iguaçu-PR. Brazil/Captivity \\
\hline & T358 & MN726911 & Reginá. French Guiana/Wild \\
\hline \multirow{13}{*}{ Mazama bororo } & $\mathrm{T} 64$ & DQ789228.2 & Curitiba-PR. Brazil/Wild \\
\hline & $\operatorname{Msg} 54^{5}$ & DQ789187.2 & São Paulo-SP. Brazil/Captivity \\
\hline & $\mathrm{T} 71^{5}$ & DQ789231.2 & Barra do Turvo-PR. Brazil/Wild \\
\hline & $\mathrm{T} 72$ & MG786263.1 & Barra do Turvo-PR. Brazil/Wild \\
\hline & $\mathrm{T} 213^{*}$ & МH593529 & Paraná-PR. Brazil/Wild \\
\hline & $\mathrm{T} 332^{5 *}$ & MH593530 & Paraná-PR. Brazil/Captivity \\
\hline & $\mathrm{T} 333^{5 *}$ & MH593531 & Paraná-PR. Brazil/Captivity \\
\hline & $\mathrm{T} 334^{5 *}$ & MH593532 & Paraná-PR -PR. Brazil/Captivity \\
\hline & $\mathrm{T} 335^{5 *}$ & MH593533 & Paraná-PR. Brazil/Captivity \\
\hline & $\mathrm{T} 336^{5 *}$ & MH593534 & Paraná-PR. Brazil/Captivity \\
\hline & $\mathrm{T} 337^{5 *}$ & MH593535 & Paraná-PR. Brazil/Captivity \\
\hline & $\mathrm{T} 338^{5}$ & MG786261 & Paraná-PR. Brazil/Wild \\
\hline & $\mathrm{T} 340^{5 *}$ & MH593536 & Paraná-PR. Brazil/Wild \\
\hline \multirow{3}{*}{ Mazama nana } & $\mathrm{T} 2$ & DQ789214.2 & Iguazu. Paraguay/Captivity \\
\hline & $\mathrm{T} 53$ & DQ789227.2 & Paraná-PR. Brazil/Captivity \\
\hline & $\mathrm{T} 185$ & DQ789210.2 & Céu Azul-PR. Brazil/Captivity \\
\hline Mazama nemorivaga & $\mathrm{T} 149$ & DQ789206.2 & Rondônia - RO. Brazil/Captivity \\
\hline Mazama gouazoubira & Msg001 & DQ789179.2 & Minas. Uruguay/Captivity \\
\hline Ozotoceros bezoarticus & $\operatorname{Sg} 1623^{*}$ & MH593537 & Salto. Uruguay/Captivity \\
\hline Mazama americana jucunda & BMNH 3.7.1.103* & MH593538 & Paraná. Brazil/Wild \\
\hline
\end{tabular}

$1,2,3,4,5$ supra index indicates sequences belonging to the same haplotype. The equal numbers indicate identical haplotypes.

* DNA sequences produced by this work and deposited at Genbank. 


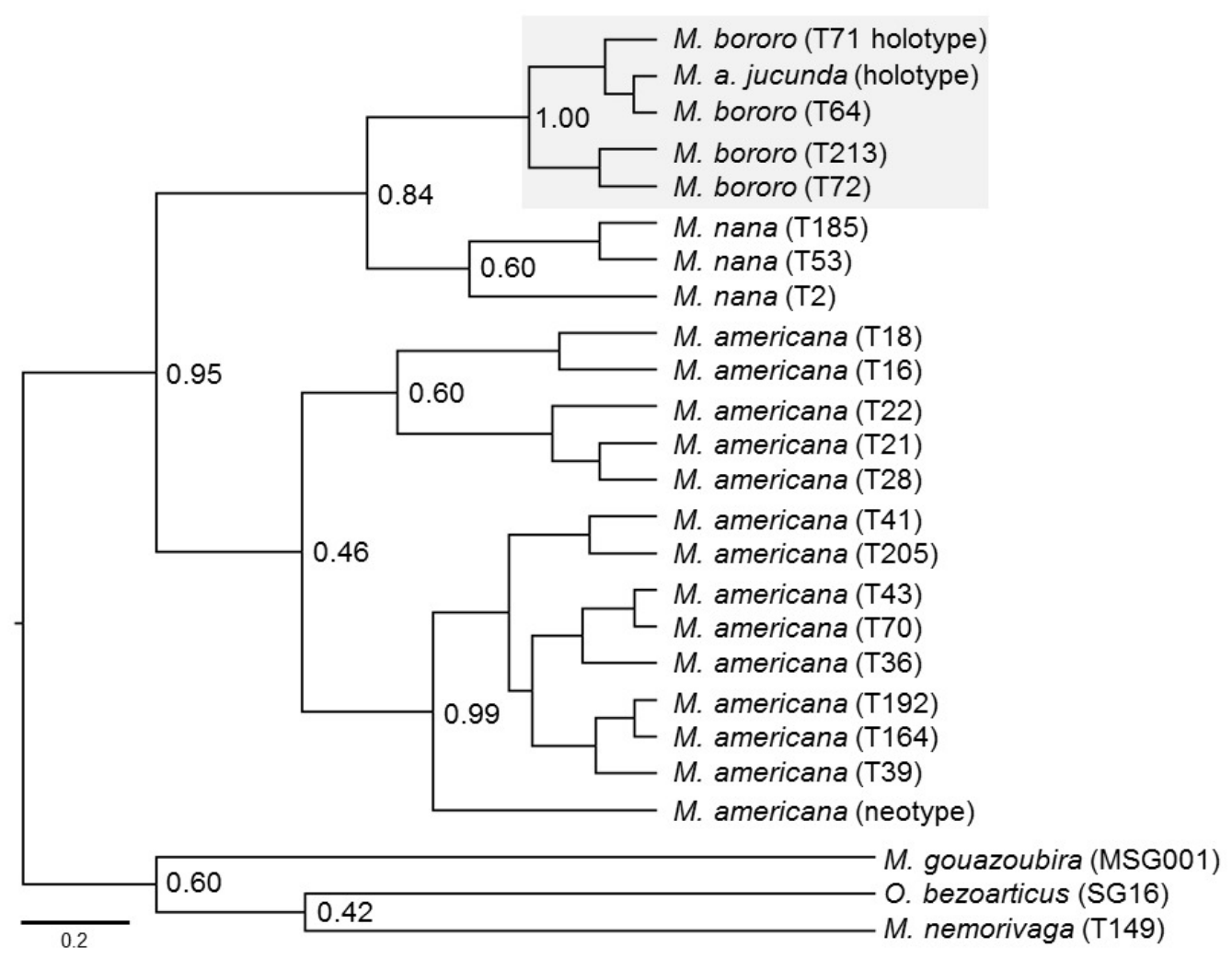

Figure 1 - Phylogenetic tree obtained from a Bayesian inference analysis of the unique haplotypes of the mitochondrial cytochrome $b$ gene, showing the close phylogenetic relationship between Mazama bororo and Mazama americana jucunda. The numbers on the nodes of the tree represent the posterior probability values. The sample identification is shown in brackets.

presented in the description of the two taxa. Therefore, the available name of the small red brocket from the southern Atlantic Forest of Brazil should be Mazama jucunda Thomas, 1913, according to the principle of priority (Article 23) of the International Code of Zoological Nomenclature) (ICZN, 1999).

Genetic resources deposited in museum collections are critically important for scientific research because they allow access to samples that would be difficult or even impossible to obtain today (Schäffer et al., 2017; Tuschhoff et al., 2020). Disputes over the validity of a given taxon can be rapidly solved with comparisons using sequence data from types (Chakrabarty, 2010). In this study, the use of DNA sequences of museum specimens was essential to clarify the taxonomical identity of M. americana jucunda, which was known from a specimen collected in 1901.

Johns and Avise (1998) suggested that the cytochrome $b$ gene has a high level of congruence within species boundaries, based on classical alpha-taxonomic studies. Our study shows that the cytochrome $b$ gene was very informative for elucidating that $M$. americana jucunda represented the same taxon as M. bororo.

DNA extracted from museum samples is usually degraded, and only short fragments can usually be amplified (Schäffer et al., 2017). In this context, the low posterior probabilities at the various nodes of the phylogenetic tree are probably related to the small size of the fragment used (224 bp). Nevertheless, the clustering of M. bororo and M. americana jucunda samples are supported by a posterior probability of 1 . The existence of two clades in $M$. americana reflects the existence of different species within the M. americana, suggesting the presence of a complex of cryptic species as previously proposed by Duarte et al. (2008) and CifuentesRincón et al. (2020).

Thomas (1913) described the subspecies M. americana jucunda based on an immature female from Roça Nova, state of Paraná, in south Brazil, close to localities where M. bororo has been recorded (Duarte et al., 2017). Current records suggest that the area of occurrence of the species in this biome is restricted to the Atlantic Forest of the Brazilian states of São Paulo, Paraná, and Santa Catarina, presenting the smallest geographical distribution of the deer species currently described (Vogliotti and Duarte 2010; Duarte et al., 2017). According to Weber and González (2003), the small red brocket deer could be considered being one of the most endangered deer species in the Neotropics, probably due to its endemism in the Atlantic Forest and the intense history of the destruction of this biome. Environmental degradation of the Atlantic Forest is an important threat to M. jucunda populations. Likewise, poaching and domestic dogs predation, due to the proximity of human populations, are important threats to the species survival (Vogliotti and Duarte 2010; Duarte et al., 2017). Currently, the species is classified as "Vulnerable" (VU) in the IUCN global assessment (Vogliotti et al., 2016). 
The scientific value of DNA barcode databases would be greatly enhanced if species were also represented by sequences of type specimens (Chakrabarty 2010), as this might mitigate some of the arbitrariness in the correct application of taxonomic names in problematic cases (Johnson et al., 2015; Mutanen et al., 2015). Morphological comparisons should always be part of this process; however, adding molecular markers analyses provide a new dimension for taxonomic research (Chakrabarty, 2010). The unequivocal application of valid names is crucial for all aspects of biodiversity research as well as for monitoring and conservation efforts (Strutzenberger et al., 2012). In this way, changing the name of the small red brocket from $M$. bororo to $M$. jucunda affects the public management and conservation policies of this fragile species in their natural habitat. Finally, we encourage the use of museum DNA of type specimens to provide a more objective and complete comparison with current specimens and consequently offer a more stable taxonomy.

\section{Acknowledgements}

We would like to thank João Boer (laboratory technician) for his assistance in the laboratory and Guilherme Garbino for the scientific and grammatical considerations. We are grateful to the Mammal curator Roberto Portela from the Natural History Museum of London for granting access to the museum specimen and for providing a bone sample. The São Paulo Research Foundation, FAPESP proc. (2013/05944-7), National Council for Research (CNPq proc. 406299/20137, 305419/2014-5), Agencia Nacional de Investigación e Innovación (ANII), Programa de Desarrollo de las Ciencias Básicas (PEDECIBA-Uruguay) and Lóreal-Unesco, for their financial support.

\section{Conflict of Interest}

The authors have no conflicts of interest to declare.

\section{Author Contributions}

$\mathrm{AMB}, \mathrm{SG}$ and JMB conceived and designed the study; AMB, SG and JMB collected the samples; AMB performed the molecular analysis and wrote the manuscript; SG and JMB made a critical review, adding improvements through comments and rewriting sentences. All authors read and approved the final version.

\section{References}

Burrell AS, Disotell TR and Bergey CM (2015) The use of museum specimens with high-throughput DNA sequencers. J Hum Evol 79:35-44.

Chakrabarty P (2010) Genetypes: A concept to help integrate molecular phylogenetics and taxonomy. Zootaxa 2632:67-68.

Cifuentes-Rincón A, Morales-Donoso JA, Sandoval EDP, Tomazella IM, Mantellatto AMB, de Thoisy B and Duarte JMB (2020) Designation of a neotype for Mazama americana (Artiodactyla, Cervidae) reveals a cryptic new complex of brocket deer species. ZooKeys 958:143-164.

Darriba D, Taboada GL, Doallo R and Posada D (2012) jModelTest 2: more models, new heuristics and parallel computing. Nat Methods 9:772.
Drummond AJ, Suchard MA and Xie D, Rambaut A (2012) Bayesian phylogenetics with BEAUTY and the BEAST 1.7. Mol Biol Evol 29:1969-1973.

Duarte JMB (1996) Guia de identificação de cervídeos brasileiros. FUNEP Editions, Jaboticabal, 14 p.

Duarte JMB and Giannoni ML (1996) A new species of deer in Brazil (Mazama bororo). Deer Specialist Group Newsletter, 13:5.

Duarte JMB and Jorge W (2003) Morphologic and cytogenetic description of the small red brocket (Mazama bororo Duarte, 1996) in Brazil. Mammalia 67:403-410.

Duarte JMB, González S and Maldonado JE (2008) The surprising evolutionary history of South American deer. Mol Phylogenetics Evol 49:17-22.

Duarte JMB, Talarico AC, Vogliotti A, Garcia JE, Oliveira ML, Maldonado JE and González S (2017) Scat detection dogs, DNA and species distribution modelling reveal a diminutive geographical range for the vulnerable small red brocket deer Mazama bororo. Oryx 51:656-664.

Gilbert C, Ropiquet A and Hassanin A (2006) Mitochondrial and nuclear phylogenies of Cervidae (Mammalia, Ruminantia): Systematics, morphology, and biogeography. Mol Phylogenetics Evol 40:101-117.

González S, Maldonado JE, Ortega J, Talarico AC, BidegarayBatista L, Garcia JE and Duarte JMB (2009) Identification of the endangered small red brocket deer (Mazama bororo) using noninvasive genetic techniques (Mammalia; Cervidae). Mol Ecol Resour 9:754-758.

González S, Mannise N, Repetto L and Maldonado JE (2015) Sex determination of three Neotropical canids by high resolution melting analysis. Conserv Genet Resour 7:643-645.

Gutiérrez EF, Helgens KM, McDonough MM, Bauer F, Hawkins MTR, Escobedo-Morales LA, Patterson BD and Maldonado JE (2017) A gene-tree test of the traditional taxonomy of American deer: the importance of voucher specimens, geographic data, and dense sampling. ZooKeys 697:87-131.

Hajibabaei M, Singer GAC, Hebert PDN, Hickey DA (2007) DNA barcoding: how it complements taxonomy, molecular phylogenetics and population genetics. Trends Genet. 23:167172.

Hall TA (1999) BioEdit: A user-friendly biological sequence alignment editor and analysis program for Windows 95/98/ NT. Nucleic Acids Symp Ser 41:95-98

Heckeberg NS (2020). The systematics of the Cervidae: A total evidence approach. PeerJ 8:e8114.

ICZN - International Commission on Zoological Nomenclature (1999) The International Trust for Zoological Nomenclature. 4th edition. International Commission on Zoological Nomenclature, London, $306 \mathrm{p}$.

Johns GC and Avise JC (1998) A comparative summary of genetic distances in the vertebrates from the mitochondrial cytochrome b gene. Mol Biol Evol 15:1481-1490.

Johnson JW and Worthington Wilmer J (2015) Plectorhinchus caeruleonothus, a new species of sweetlips (Perciformes: Haemulidae) from northern Australia and the resurrection of P. unicolor (Macleay, 1883), species previously confused with P. schotaf (Forsskål, 1775). Zootaxa 13985:491-522.

Miller MA, Pfeiffer W and Schwartz T (2010) Creating the CIPRES Science Gateway for inference of large phylogenetic trees. In: Proceedings of the Gateway Computing Environments Workshop (GCE). New Orleans, pp 1-8.

Mutanen M, Kekkonen M, Prosser SW, Hebert PDN and Kaila L (2015) One species in eight: DNA barcodes from type specimens resolve a taxonomic quagmire. Mol Ecol Resour 15:967-984. 
Sambrook J, Fritsch E and Maniats T (1989) Molecular Cloning: A Laboratory Manual. 1st edition. Cold Spring Harbor Press, New York, $1659 \mathrm{p}$.

Schäffer S, Zachos F and Koblmüller S (2017) Opening the treasure chest: a DNA-barcoding primer set for most higher taxa of Central European birds and mammals from museum collections. PLoS One 12:e174449.

Strutzenberger P, Brehm G and Fiedler K (2012) DNA barcode sequencing from old type specimens as a tool in taxonomy: A case study in the diverse genus Eois (Lepidoptera: Geometridae). PLoS One 7:e49710.

Thomas O (1913) On certain of the smaller S. American Cervidae. Ann Mag Nat Hist 8:585-589.

Thompson JD, Higgins DG and Gibson TJ (1994) CLUSTAL W: Improving the sensitivity of progressive multiple sequence alignment through sequence weighting, position-specific gap penalties and weight matrix choice. Nucleic Acids Res 22:4673-4680.

Tuschhoff EJ, Hutter CR and Glor RE (2020) Improving sustainable use of genetic resources in biodiversity archives. PeerJ 8:e8369.

Vogliotti A and Duarte JMB (2010) Small brocket deer Mazama bororo (Duarte 1996). In: Duarte JMB and González S. (eds) Neotropical Cervidology. Biology and Medicine of Latin American Deer. 1st edition. Funep/ IUCN, Jaboticabal, pp. 172-176.

Weber M and González S (2003) Latin American deer diversity and conservation: A review of stats and distribution. Ecoscience $10: 443-454$

\section{Internet Resources}

Dorado-Pérez G (2012) Secuenciación del ADN. In: Díaz NA, Dorado-Pérez G, Cejudo AG, Novo JVJ, Galisteo EM, Peña CAP, Peinado JP, Aldave MT and Fiñana IT (Eds) Prácticas Generales de Bioquímica y Biología Molecular. Universidad de Córdoba, https://www.uco.es/organiza/departamentos/ bioquimica-biol-mol/pdfs/47\%20SECUENCIACION\%20 DNA.pdf (accessed 10 February 2012).

Rambaut A (2010) FigTree 1.3.1. Institute of Evolutionary Biology, University of Edinburgh, Edinburgh, http://tree.bio.ed.ac.uk/ software/figtree/ (accessed 10 June 2013).

Vogliotti A and Duarte JMB (2012) Veado-mateiro-pequeno (Mazama bororo). In: Duarte JMB and Reis ML (eds) Plano de ação nacional para a conservação dos cervídeos ameaçados de extinção. Instituto Chico Mendes de Conservação da Biodiversidade. 1st edition. ICMBio, Brasília, pp 70-79, https:// www.icmbio.gov.br/portal/images/stories/docs-plano-de-acao/ pan-cervideos/cervideos-web.pdf (accessed 15 January 2013).

Vogliotti A, Oliveira ML and Duarte JMB (2016) Mazama bororo. The IUCN Red List of Threatened Species 2016: e.T41023A22155086 (accessed 10 March 2021).

Associate Editor: Antonio Matteo Solé-Cava

License information: This is an open-access article distributed under the terms of the Creative Commons Attribution License (type CC-BY), which permits unrestricted use, distribution and reproduction in any medium, provided the original article is properly cited. 